\title{
A Study on Vegetable Export for the Economic Development of Bangladesh and Its Entrepreneurial Opportunities for Young Educated Bangladesh People
}

\author{
Kazi foyez Ahmed \\ Bangladesh Academy for Rural Development (BARD), Kotbari, Comilla, Bangladesh \\ PO box 3503
}

\begin{abstract}
This study tries to explain the prevailing vegetable supply chain system in Bangladesh which impact on International Market linkages includes some markets, number of intermediaries, and involvement of Stakeholder. Next, it shows many limitations within the present supply chain where the issues of export of vegetable supply chain have discoursed thoroughly. Then, the influences of lack of effective supply chain linkages are discussed. The main difficulties met by the growers, Exporter, and negotiators were deficiency of money, Training, production, Packaging Knowledge, poor communication and transport services, lack of adequate storage services, lack of suitable market info, higher market tolls, deficiency of market facilities, etc. The growers and intermediaries also suggested some solutions to those difficulties. As vegetables are perishable products, the study provides an overview of the issues and solutions within the use of cargo space at the airport. The govt should take the required steps to undo these problems and thus extend the effectiveness of vegetable supply chain export marketing in Bangladesh. Here shows a proposed vegetable supply chain and policy level suggestion for International Market linkages. At present Bangladesh is in the demographic dividend. It includes a large number of educated unemployed. This study provides a detailed explanation of how to start a new business to grow as an entrepreneur. These people can play a significant role in the country's GDP by exporting vegetables from the country by obtaining export licenses and earning foreign exchange.
\end{abstract}

DOI: $10.7176 /$ RHSS/11-20-09

Publication date:October $31^{\text {st }} 2021$

\section{CHAPTER I: INTRODUCTION}

General Introduction

This Chapter Represent Background of the study, the significance of the study, the Scope of the study, Problem statement, Research Objectives.

\section{Background of the study}

Bangladesh has seen rapid export growth over the last decade, increasing from a mere \$7.521 billion in FY 2004-05 to a tremendous $\$ 45.50$ billion in FY 2019-20. Including $\$ 38.20$ billion from ready-made clothing goods in the United States. However, it is also true that our export basket is filled with only one specific product category, as Readymade Garments (RMG) accounts for nearly $83.95 \%$ of the total export earnings of the country. Such an unsustainable concentration poses a potential danger, arising primarily from external market shocks and market access disturbances, to maintain our long-term export growth trend. It, therefore, takes an hour to diversify our export base in terms of the form of commodity, and the ideal candidates for such an initiative are agricultural and agro-based products with their high export potential.

Bangladesh is rich in the production of agro-based products and, over the last three decades, has experienced significant agricultural growth through the implementation of Good Agricultural Practices (GAPs), the modernization of production and harvesting practices, and the use of improved and sustainable technologies. Currently, through the simultaneous increase in productivity and agriculture, the country is self-sufficient in cereal food production. Vegetables play a very important role, among other agricultural products, in promoting domestic food demand and ensuring food security. For a wide variety of vegetable crops, the climate of Bangladesh (both tropical and sub-tropical) and the soil are sufficient. Vegetables contribute to 3.2 percent of the agricultural Gross Domestic Product in Bangladesh. Around 26.7 million tons of vegetables were produced across Bangladesh in the 2018-19 fiscal year. Although a very small portion of cultivable land is used for vegetable cultivation, between fiscal years 2013-14 and 2018-19, there was a significant increase in production of 37.63 percent.

In the fiscal year 2018-19, around 26.7 million tons of vegetables were produced on around 1.25 million hectares of land, according to the Department of Agricultural Extension (DAE). 
Vegetable Cultivation uses of Land Fiscal Year 2013-14 To 2018-19

\begin{tabular}{|c|c|c|}
\hline Fiscal year & Land in million hectares & \multicolumn{1}{|c|}{$\begin{array}{l}\text { Cultivated amount in } \\
\text { million tons }\end{array}$} \\
\hline $2013-14$ & 0.97 & 19.40 \\
\hline $2014-15$ & 0.99 & 21.04 \\
\hline $2015-16$ & 1.06 & 20.00 \\
\hline $2016-17$ & 1.08 & 23.60 \\
\hline $2017-18$ & 1.17 & 25.63 \\
\hline $2018-19$ & 1.25 & 26.70 \\
\hline
\end{tabular}

Analysis of the trends in exports of vegetables from Bangladesh in recent years reveals an encouraging sign of the export potential for this sector Bangladesh's vegetable export earnings in July-March of the current financial year 2019-20 stood at \$146.71 million, according to data from the Export Promotion Bureau, which is 79.51 percent higher than the earnings in the same period last fiscal year. 70 Different types of vegetables are exported from Bangladesh to more than 53 countries in the world, with Bangladesh's expatriate markets being restricted to buyers. In FY 2018-19, our fresh vegetable export market comprised about 46.3 percent of Middle Eastern countries (Saudi Arabia 22.08 percent, UAE 7.67 percent, Kuwait 6.84 percent, Qatar 6.80 percent, Bahrain 1.65 percent, Oman 1.26 percent), 25.87 percent of the EU zone (UK 19.09 percent, Italy 4.83 percent and other 1.95 percent), 15.07 percent of East and South-East Asian countries (Mala 19.09 percent, Italy 4.83 percent and other 1.95 percent).

Since the early 1990s, different development and export promotion initiatives have been underway in Bangladesh, given the potential of the vegetable sector. Nevertheless, Bangladesh's production in the vegetable sector and the accompanying export output are often faced with a multitude of problems. Both on the domestic front and in the export market, the sector faces many constraints. Supply-side constraints, supply chain, and value chain problems, and policy-induced steps in importing countries. Those who have been working in this sector for a long time are facing various problems in exporting vegetables. In particular, lack of proper knowledge in the field of sending goods according to the demand of the importer, production, and marketing of related products. At present most of the educated manpower in Bangladesh is unearned. Appropriate training of a new entrepreneur and proper guidance on what kind of procedures and procedures to follow in case of export of goods will be given from this study.

\section{The significance of the study}

Worldwide has taken In SDG which has 17 Goals, which will be operated within 2030. My research is hit SDG's second goal that is GOAL 2: Zero Hunger. How is it related to zero hunger? In SDS Goal 2: said End hunger, achieve food security, improved nutrition, and promote sustainable agriculture. Also, SDGs Goal 12: Ensure Sustainable Consumption and Production Pattern. Here said Reduce Food Losses along Production and Supply chain including Post Harvest losses.

Increase investment in rural infrastructure, agricultural research and extension services, technology development, and plant and livestock gene banks to enhance agricultural productive capacity in developing countries, including through enhanced international cooperation. In particular, the least developed countries, including by the simultaneous abolition of all forms of agricultural export subsidies and all equivalent export measures, are correcting and preventing trade barriers and distortions in world agricultural markets.

Take measures to ensure the proper functioning of the markets for food commodities and their derivatives, and to promote timely access to market information, including food stocks, to help minimize excessive food price volatility.

\section{Scope of the Study}

On the other hand, the PSPS objective new village movement for sustainable development as per rural and socioeconomic development. Bangladesh is an agricultural country that may produce a large number of fresh vegetables in a rural area, but they do not get the proper price. For example, in South Korea $1 \mathrm{~kg}$ tomato price $3000 \mathrm{KRW}$ in BDT 210tk, on the other hand in Bangladesh $1 \mathrm{~kg}$ Tomato price average BDT 30tk in Korea won $430 \mathrm{KRW}$. In full pic season different place of the rural area only 5 tk, that means $70 \mathrm{KRW}$. We have no proper vegetable storage facility and proper supply chain. The Huge volume of production occurs in pic season. The production of the product meets the requirement of the local area and stay marginal safety. The Farmer does not get the proper amount of money they become looser day by day. As with Tomato different vegetables are produced in our country and meet the requirements of EOQ (Economic Order Quantity) situated marginal safety. If this place installs a proper vegetable store and time-demanding supply chain market, then a new village moment concept will be implemented.

The country Bangladesh's 7th five-year plan has agriculture sector development by using supply chain continues to be the largest source of employment and a major contributor to poverty reduction. Which is related 
to my research topics.

\section{Problem statement}

Bangladesh is known as one of the world's developing countries and is always described as a rural country with more than $50 \%$ of the population engaged in agriculture. It is the river's land and has huge natural and unskilled human resources.

The purpose of this research is to recognize the contribution of exports to Bangladesh's economic growth and also to address the various suggestions and strategies that have been or are being adopted by the government to increase its exports. This leads to the following questions being posed by a researcher:

1. What are the methods and prospects for improving the exports of vegetables?

2. What is the Unemployed Educated Human Resource Opportunity for Bangladesh's Vegetable Export and Economic Growth?

\section{Research Objective}

\section{General Objectives of the study}

The general objective of the study to explore the present Scenario and Future Direction of the Technology-based Vegetable Export for the Economic Development of Bangladesh and its Entrepreneurial Opportunities for Young Educated Bangladesh People.

\section{The specific objectives were to:}

$>$ Identify the evolution of the present Vegetable market and factors;

To analyze whether the existing local supply chain can meet the requirements of international trade;

$>$ To suggest a proposed technology-based supply chain system for effective vegetable International market Linkage;

$>$ To identify opportunities Freshers entry to Vegetable Export marketing as an entrepreneur.

\section{CHAPTER II: LITERATURE REVIEW}

(Agudo, 2005) The vegetables are a crucial Element of the human food basket for his or her taste, and nutritional and health benefits. Consumption of at least 400 grams of fruit and vegetables per day (excluding potatoes and other starchy tubers) by the Food and Agriculture Organization (FAO) and the World Health Organization (WHO) is recommended for the prevention of chronic diseases such as heart disease, cancer, diabetes, and obesity, as well as the prevention and alleviation of many micronutrient deficiencies

(Asian Productivity Organization, 2007) The Marketing System for Agricultural Products suggested that Bangladesh's agricultural marketing system is inefficient due to different regions, fragmented development areas, natural disasters, and relatively poor infrastructure conditions. The report suggested that two approaches should be adopted. The First approach is the establishment of regulated markets, which are set up to regulate the conduct of market functionaries, promote grading, and standardization of products, collect and disseminate information. The second approach is the establishment of central wholesale markets, which will provide facilities for assembling a large volume of products, which are properly stored, graded, and packed to facilitate their auctioning. The author also highlighted some major aspects namely the infrastructure required for efficient marketing of vegetables. One aspect, the author mentioned, was the marketing arrangement in terms of the extent of coercion exercised by marketing institutions.

(Fazlur, 2008) A study on "Agricultural Marketing System in Bangladesh" highlighted the lack of market information as one of the reasons for the low price received by the growers. The author mentioned that public sector market information systems like the Directorate of Agricultural Marketing, Directorate General of Food, and the Food Planning and Monitoring Unit are not updated so the existence of these systems is not much help for the farmers. The author also urged private enterprises to invest in this marketing system.

(Malakar, 2006) A study on "Agricultural Marketing Systems in Bangladesh" mentioned the constraints regarding the improvement of marketing performance such as the preponderance of various marketing acts, poor infrastructure. The author mentioned that only farmers could not increase the efficiency for which government support and private firms' investment were also required. He mentioned there were some agricultural markets in Bangladesh from which agricultural produces were traded such as rural wholesale markets, urban wholesale markets, urban wholesale come retail markets, and urban retail markets, which had little connection with the market information system. Finally, the author recommended that the marketing system of farm products in Bangladesh needed to be based on modern and scientific lines. Modern techniques like contract Farming, development, and modernization of primary markets, retail outlets should be introduced.

(Faraja Mlelwa, 2013) In addition to health impacts, the vegetable is a high-value crop that can increase income and may contribute to poverty reduction in underdeveloped countries. Few studies have observed that small-scale vegetable farming has the potential for the reduction of poverty. A study in Tanzania observed a 
significant positive contribution of vegetable production to household income and thereby reduction in poverty that increased food security, affordability to healthcare, and use of educational facilities.

(Hossain \& Hossain, 2013) "Some Observations over Supply Chain: With Reference to Vegetables Market of Bangladesh" Mentioned to explain the prevailing vegetable supply chain system in Bangladesh which incorporates the number of markets, number of middlemen, and number of financing institutions. There are broadly four sorts of the market within the existing supply chain of vegetables in Bangladesh. These are Rural Primary Markets, Assembly and Secondary Markets, Terminal Markets, Other Markets: direct on-farm sales and, the utilization of pre-harvest contractors who purchase the produce while it's still on the trees and arrange for harvesting, packaging, and transport to wholesale outlets. Then, the impacts of lack of effective supply chain linkages are discussed. Finally, they show a proposed vegetable supply chain for Bangladesh. With the event of the marketing system, both private and public investments are needed to return forward.

(Weinberger \& Lumpkin, 2007) The study identified a scarcity of adequate transport and logistics as barriers to scaling up vegetable production. Developing countries' horticultural products and manufactured products are in demand on both domestic and foreign markets and provide good opportunities for poverty reduction because it raises income and creates jobs, so care must be taken to ensure that small and poor farmers are not excluded from these market sectors' opportunities.

(Levitt, 2016) As vegetables have both health and economic effects, these are potential items for trade across the countries. consistent with COMTRADE and ITC statistics, the export trade of fresh vegetables was US Dollar 69.98 billion in 2016 and US Dollar 58.63 billion in 2012. Within five years between 2012 and 2016, the export marketplace for fresh vegetables expanded by 1.19 times. The changing economic scenario of the world, creating new opportunities for developing countries to export fresh vegetables. With the dropping value of real and tries to scale back costs, British fresh vegetable importers are receiving to source more fresh produces from developing nations of Africa.

(Wisner, Tan, \& Leong, 2012) Bangladesh is an agricultural country that will produce an outsized number of fresh vegetables for internal consumption and export to global markets. However, this country couldn't perform well in fresh vegetable production and international trade. consistent with the Food and Agriculture (FAO) statistics, Bangladesh produced 1.36 million metric plenty of fresh vegetables in 2014 and was the 18th largest producer. In contrast, the tiny South Asian neighbor Nepal produced 3.42 million metric plenty of fresh vegetables in 2014. within the export of fresh vegetables, Bangladesh has almost no existence. it had been ranked 82nd within the global export market of fresh vegetables in 2016 and therefore the export was only US Dollar 44.5 million. Though a possible country for fresh vegetable produces, Bangladesh couldn't become a serious producer and exporter of the merchandise. The failure of the country within the production and export of fresh vegetables is usually considered because of the consequence of an ineffective supply chain. Lack of access to markets may be a for farmers to urge economic gains for the production of fresh vegetables is a major issue. The purpose of this paper is to study the features of Bangladesh's downstream vegetable supply chain and to examine whether the current local supply chain would meet the needs of foreign trade. II. Literature Review The downstream of the availability chain is liable for connecting the producers to consumers. The activities associated at this stage of the availability chain are buying or collecting goods from producers, transportation, warehousing, analyzing customer needs and fulfilling customer requirements, locating logistic facilities, and planning other services necessary to facilitate the transfer of products from producers to consumers.

(Tasnoova \& Izumi Iwamto, 2006) The downstream of the fresh vegetable supply chain in Bangladesh consists of 5 sorts of intermediaries - Faria, Bepari, Vegetable storekeeper, Wholesaler, and Retailer. Faria is little traders who procure products from growers and suppliers to Merchant, retailers, and consumers. they are doing business with small-cap and procure vegetables of small quantities. Merchants are professional traders to acquire fresh vegetables in great quantity from growers and Faries and provide them to Vegetable storekeepers. Vegetable storekeepers are large business establishments with fixed establishments and work as commission agents to link between Merchant and retailers. Paikars are wholesalers who procure from vegetable storekeepers the supply of vegetables and sell them to supermarkets or large consumers. The largest supplier of fresh vegetables to customers in supermarkets. These intermediaries will not carry out transportation, storage, grading, packaging, funding, and risk-bearing supply chain functions. because the vegetable trade in Bangladesh isn't a proper sector, the financing during this sector mostly comes from the self-financing of the intermediaries.

In absence of formal policy insurance systems, all risks associated with the assembly and marketing of fresh vegetables are borne by the growers and intermediaries in Bangladesh (Matin, et al., 2008).

The fresh vegetable growers are small or marginal farmers and can't reach customers due to inadequate market information and financial ability to undertake necessary logistics. this example has enabled the Merchant and Vegetable storekeepers to exercise control on the availability chain operations of vegetables. The exporters get a supply of fresh vegetables mostly from Vegetable storekeepers. 


\section{CHAPTER III: METHODOLOGY}

\section{Nature of the Study:}

This is Descriptive Research because the objective of this research is to evaluate the capability downstream supply chain of fresh vegetables to meet the requirements of the exporters. It will be a case-control study. The exporters of fresh vegetables are a case group who evaluates the capabilities of the supply chain from their experiences in international trade. The local traders are a control group who evaluates the capabilities of the supply chain from their experiences of business in local markets. A comparison of opinions of case and control groups can identify the differences, if any, of the downstream supply chain and useful to assess the capability of the supply chain to meet the requirement of international trade. The definition of case and control groups for this paper will be the following way.

Case-1: Firms \& people currently involved in exporting vegetables in other countries.

Case-2: Firms engaged in trading vegetables in the domestic market and not involved in exporting vegetables. This group mostly includes the Trader and some large Trader.

Case-3: Involvement of Stakeholders exporting vegetables in other countries.

\section{Method of Data Collection:}

Data will be collected from secondary and primary sources. Secondary Data were collected from research papers, articles, websites, journals, newspapers \& analyses of Different Video documentaries on export Vegetable marketing, etc.

\section{CHAPTER IV: CURRENT VEGETABLE PRODUCTION IN BANGLADESH \& EXPORTING COUNTRIES:}

In Bangladesh, vegetable crops occupied only 2.64 percent of total cultivable land. On the other hand rice, cultivable land is 74.85 percent. Because Bangladesh is a Land of River. Most of the rivers have no wall on either side. So, most of it gets flooded during the rainy season. There is no other way but to produce paddy. The per capita supply of vegetables is one-fifth of cereal production while it is double in the case of developed countries. It is because farmers find few incentives and encouragements to grow vegetables. The overall distribution of cropped area is shown below:

Figure 1: Area under Cultivation of different Crops in Bangladesh, 2015-2016

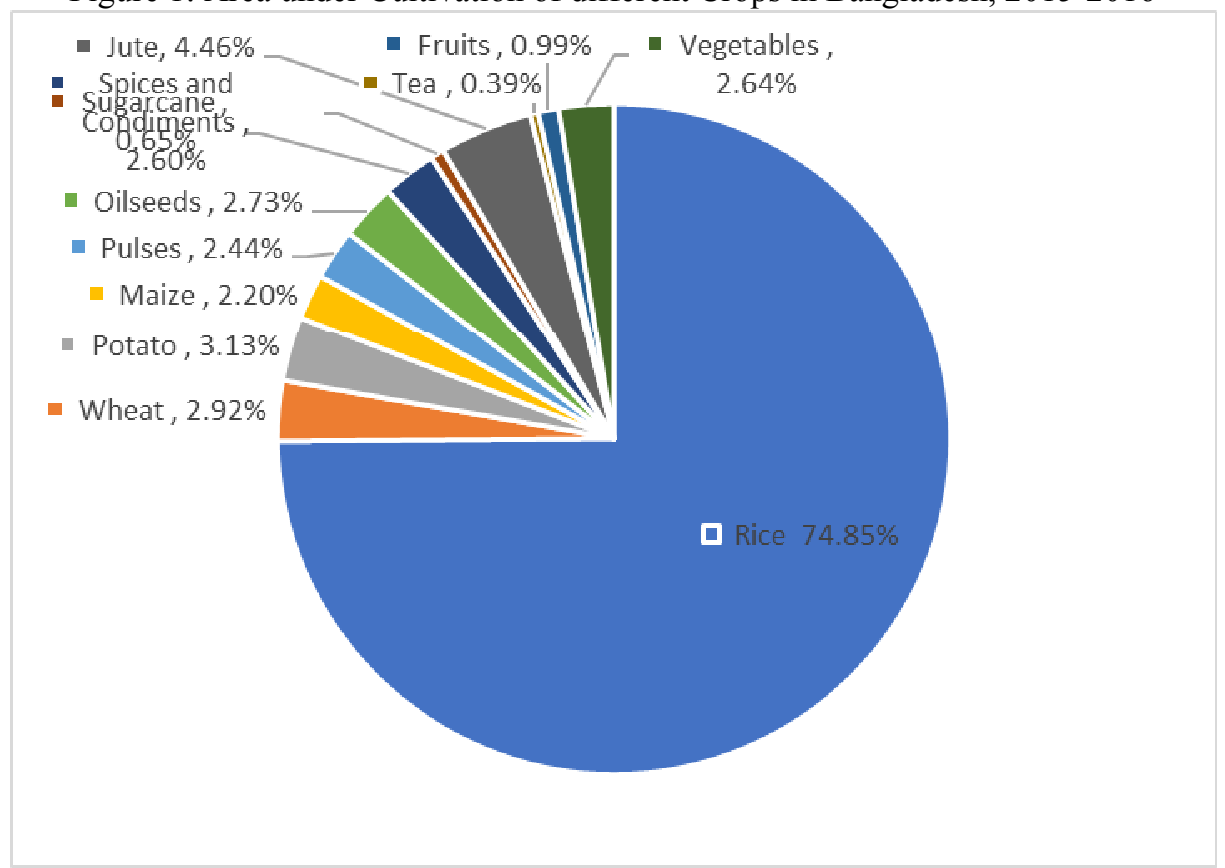

\section{Source: Bangladesh Bureau of Statistics Agricultural Wing.}

In the above figure, we see that the distribution of cropped area for vegetables is less than some other cereals. It is much less than that of rice. However, there is a very lucrative market for vegetables at the national and international levels. But still, the production is not enough to meet the demand of all these markets and the quality of produced vegetables is not good enough to meet the requirements of those markets.

\section{Current Vegetable Production in Bangladesh:}

Bangladesh is a land of rivers. Therefore, vegetables are produced in relatively high lands. About 157 types of 
vegetables are produced in Bangladesh. Bangladesh lags far behind in international Vegetable market competition due to a lack of knowledge of proper production rules, and lack of proper knowledge about packaging including the processing of manufactured products. The highest production of vegetables in Bangladesh is in Ten districts. The district Name is Jashore, Munshiganj, Narsingdi, Gazipur, Moulvi Bazar, Habiganj, Cumilla, Bogra, Mymensingh, Chittagong. Brinjal, Pumpkin, Radish, Arum, Tomato, Beans, Cauliflower \& Others.

Figure 2: Area Under Vegetable (Winter \& Summer) in Bangladesh, 2015-2016 Percentage

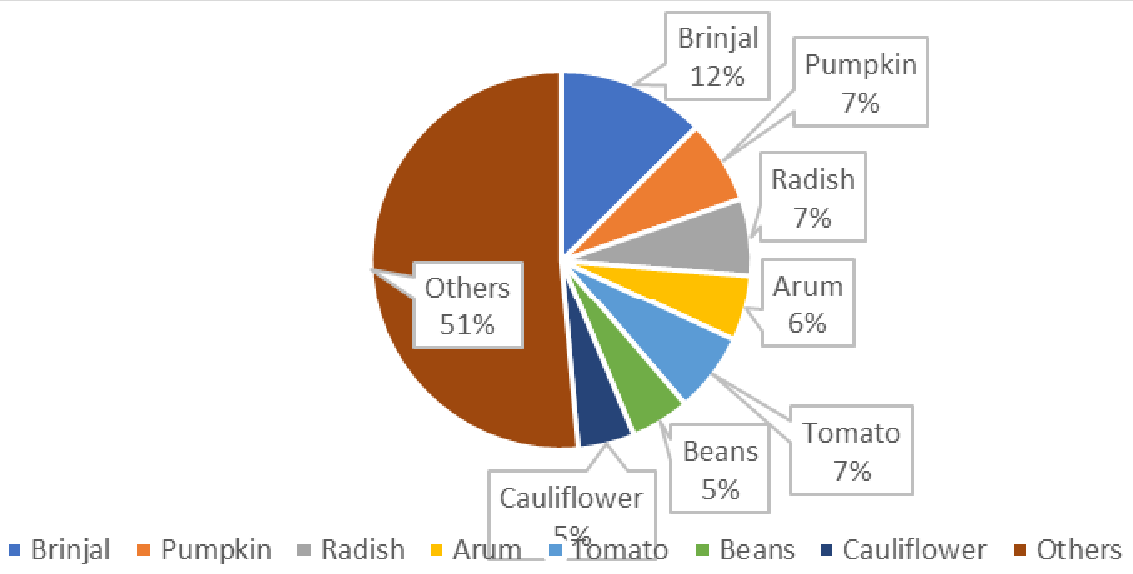

Source: (BBS, 2017)Bangladesh Bureau of Statistics (BBS) Yearbook of Agricultural Statistics-2017 page 35.

In the above figure we see that the Brinjal Production is a Higher percentage, which is $12 \%$, On the other hand, Pumpkin, Radish, Tomato is $6 \%$. But others which are shown $51 \%$ that most of the portion covered potato production in Bangladesh.

Existing Vegetable Supply Chain in Bangladesh for Domestic Market:

Retailers generally purchase vegetables from the Merchant through Vegetable storekeepers and sell them directly to the consumer. They have a permanent shop in the retail market, or they have markets on open-air outside the markets called footpath. However, in rural areas retailers purchase vegetables directly from the growers and sell them to rural consumers. In general, the vegetable supply chain starts from vegetable growers. From them, Merchant buys vegetables. From many Merchant, Vegetable storekeepers buy vegetables who later sell them to wholesalers. Then vegetable retailers buy from the wholesaler and sell them to the ultimate consumer. In this way, vegetables reach from vegetable growers to ultimate consumers. 
Figure 3:Existing Vegetable Marketing Channel in Bangladesh.

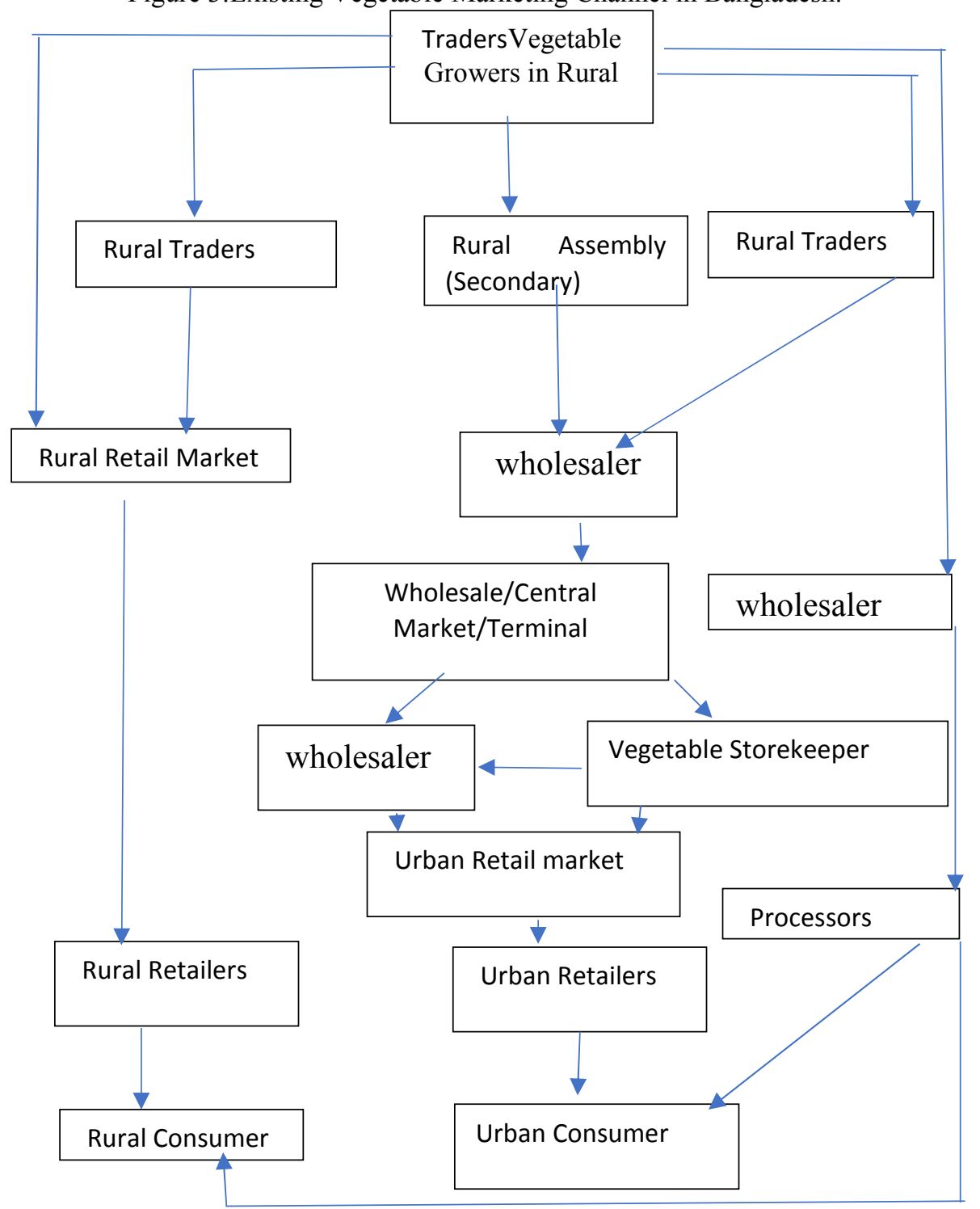

Source: (Alam Md Jhanagir, 2010)

Existing Vegetable Supply Chain in Bangladesh for International Market:

Rural-urban traders buy products from vegetable growers and take them to terminal markets or wholesale markets. Goes to the wholesale market and sells the goods to the export agent. Export agents sort package the goods at a specific place and send the goods to the exporters in mini trucks at the air cargo terminal. The screening process is completed at the air cargo terminal, the goods enter the air cargo, and by air, the goods reach the destination country. Importers from different countries receive products and send them to different department stores \& Vegetable Market. The Final consumer purchases products from different department stores and Vegetable Market. 
Figure 4:Present Scenario of Vegetable Export Supply Chain

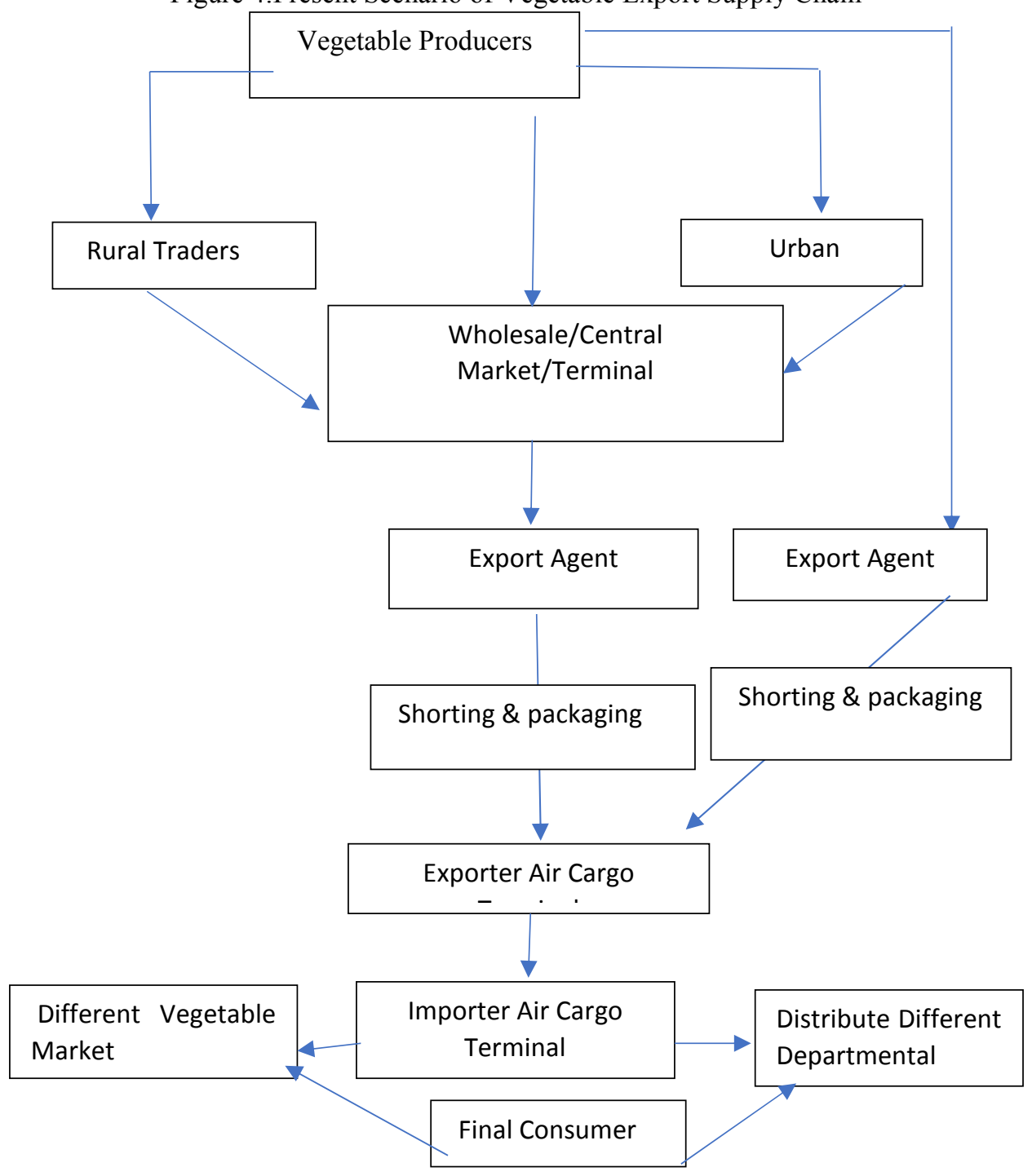

Present Scenario of Bangladesh:

More people live per square kilometer than the size of Bangladesh. At present Bangladesh is in the demographic dividend stage. At present, the number of people in Bangladesh is more than 15 to 60 years. Therefore, it can be said that Bangladesh has huge working manpower. It is easily possible to earn more foreign exchange by converting it into human resources. 
Figure 5:Present Scenario of Bangladesh

\begin{tabular}{|ll|}
\hline$>$ & The total area of Bangladesh: 147570 Sq. Km \\
\hline$>$ & Total division: 8 Divisions \\
\hline$>$ & District: 64 \\
\hline$>$ & Upazila: 545 \\
\hline$>$ & Union: 4543 \\
\hline$>$ & Village: 87223 \\
\hline$>$ & Population: 144043697 \\
\hline$>$ & Live in village 110480514 \\
\hline$>$ & Live in town 33563183 \\
\hline
\end{tabular}

Source: Bangladesh Bureau of Statistics. (BBS)

Bangladesh Agriculture at a Glance:

Due to the geographical location of Bangladesh, many vegetables are produced. About three-quarters of the people in Bangladesh live in villages. So, most of the vegetables are produced in the countryside and reach from the village to the city, from the city to different parts of the world. If this huge population can be trained in marketing in the international market through the packaging and processing of vegetable products, then Bangladesh will be able to play a significant role in the GDP of this sector.

Figure 6:Bangladesh Agricultural Land uses.

\begin{tabular}{|l|l|}
\hline Total family & $2,86,95,763$ \\
\hline Total farm holding & $1,51,83,183$ \\
\hline Total Cultivable land & 8505278.14 hectare \\
\hline Total irrigated land & 7124895.41 hectare \\
\hline Cultivable waste & 204366.24 hectare \\
\hline Cropping intensity (\%) & 190 \\
\hline Single cropped area & 2440659.10 hectare \\
\hline Double cropped area & 3820637.14 hectare \\
\hline Triple cropped area & 1637762.79 hectare \\
\hline Net cropped area & 7908771.50 hectare \\
\hline Total cropped area & 15034071.60 hectare \\
\hline $\begin{array}{l}\text { Contribution of the agriculture } \\
\text { sector to GDP }\end{array}$ & $15.96 \%$ \\
\hline
\end{tabular}

Source: Bangladesh Bureau of Statistics. (BBS) 
Figure 7: Bangladesh Agroecological Regional Map



CHAPTER V: INVOLVEMENT OF BANGLADESH FRUITS, VEGETABLES \& ALLIED PRODUCT EXPORTER'S ASSOCIATION (BFVAPEA) \& EXPORTING COUNTRIES

BFVAPEA is that the only association in Bangladesh for the export of horticultural fresh vegetables, fruits, betel 
leaf, and allied products to the worldwide market. Presently there are over 500 members are actively involved in the business of fresh fruits and vegetable export to the different destinations of the world, although Bangladesh has started the export of horticultural produces in 1973, but BFVAPEA formally established in 1984 for export promotion and diversification. Export of fresh horticultural produces is usually carried on a consignment sale basis under the common platform of BFVAPEA. The EU exporting countries (the United Kingdom, Germany, Italy, France, Switzerland, Belgium, Denmark, Spain, Sweden, Greece, and Ireland) are the second-largest importing regions for Bangladesh, with the highest number of fresh vegetables and fruit being exported to Central Eastern countries such as KSA, UAE, Qatar, Oman, Bahrain, and Kuwait. In two other Asian nations, such as Malaysia and Singapore, Bangladesh only exports a few quantities of fresh vegetables and fruit. Among the two countries in North America, only Canada is their customer. Exporters have set the objectives of disciplining the export of horticultural crops, ensuring the quality of export crops, and carrying outgrowth activities for the promotion and diversification of exports. Under the popular platform of the Bangladesh Fruits, Vegetables \& Allied Commodity Exporter's Association (BFVAPEA). exports of fresh fruits and vegetables is mostly carried on a "Consignment sale basis".

\section{Bangladesh Fruits, Vegetables \& Allied Product Exporter's Association (BFVAPEA) Activities:}

1. The diversification of agricultural production on export, which contributes to value and poverty alleviation.

2. To satisfy the aspirations of horticultural export growers in Bangladesh, and to further enhance export activities within the region.

3. to market, protect, and safeguard the interest of Exporters engaged in exporting of Fruits, Vegetables \& Allied Product items by Air, Sea, and Road in connection herewith.

4. The Association is functioning as a service provider to producers, exporters of Bangladesh, and importers of the worldwide market.

5. To serve global importers with better quality vegetables, fruit, and allied products and gain remittance by exporting fresh produce.

6. to seek out out the new global marketplace for export of horticultural fresh produces from Bangladesh with suits roles and regulation of importers country.

7. By growing exports of fresh vegetables and allied products from Bangladesh, to generate rural jobs and boost rural incomes for rural poor people, also as agronomic and horticultural growers of Bangladesh.

8. Diversification of export agricultural production, which helps to establish considerable contrition on income and poverty alleviation by generating jobs for the rural poor and Bangladeshi farmers

9. Help and promote exporters to explore more Agric business investment and export opportunities through improving our export quality as better than our competitors like India, Pakistan, Thailand.

\section{Present Scenario of vegetable export supply chain in Bangladesh:}

In the case of air freight, 76 percent of the freight cost falls on the product price. In the case of the export of goods from Bangladesh, the RMG sector is getting priority in the case where vegetables are covered under the perishable product but in reality, it is not being implemented. In that case, the traders involved in vegetable export are facing any loss. Through various documentary analyzes, it has been observed that vegetable exporters are seeking the benefit of transporting $25 \%$ of the total cargo system.

There are currently two Exclusive Detection Machine (EDS) machines at the Hazarat Shahjalal airport for scanning products, and exports are being discouraged. Sometimes two Exclusive Detection Machine (EDS) machines are not working properly. But they charge a 5tk per $\mathrm{kg}$ screening charge. Exporter Association Said they provide Handling Charge But they don't any opportunity as per loading unloading. There is no available space in the air Cargo Village area. Same place exporter put their Garments product, Vegetable \& Fish Item also. It's a Hygienic issue as per food product exports. There is an inadequacy of adequate trolleys. Even after the vegetables arrived at the airport at the right time, the screening process was delayed due to an adequate screening machine. As a result, the aircraft left without leaving the goods. As a result, exporters are facing losses. There is no suitable storage Facility in the airport Cargo Area.

Jashore, Munshiganj, Narsingdi, Gazipur, Moulvi Bazar, Habiganj, Cumilla, Bogra, Mymensingh, Chittagong district are playing a central role in the export of Vegetable in the international marketplace from Bangladesh. The Highest Exportable product is Brinjal, Pumpkin, Radish, Arum, Tomato, Beans, Cauliflower \& Other. From there the goods are going to Europe, the Middle East, and other countries. Despite having all kinds of products, we are not able to enter the European market. Due to the proper packaging, the weight of the packaging is high, and we are not able to provide quality products.

The companies that are importing products from Bangladesh abroad, especially vegetables, have come to Bangladesh more than once and are giving instructions as per their requirements on what kind of products they want. In line with the guidelines, the Department of Agriculture Extension was provided various training years 
of 2018 on Production, production monitoring, and export packet packaging of lemon \& dimensional vegetables in 8 districts in 25 Upazila. The district Name is Dhaka, Narsingdi, Gazipur, Sylhet, Moulvi Bazar, Habiganj, Cumilla, Bogra.

\section{Data Analysis:}

\section{Higher Cost of Production:}

The four dimensions of the vegetable supply chain of Bangladesh are analyzed in the literature review to find if there are differences among the exporters and local traders regarding the supply chain. The taste and quality of the products carried by the supply chain are good enough to meet the requirements of both exporters and local traders. Local traders consider the cost of production low enough, but the exporters disagree with it. The vegetable market in Bangladesh is a sales market and the suppliers can cover the cost of the supply chain by selling at a higher price to consumers. The international market of vegetables is competitive, and many nations can supply vegetables at a low price. It is the reason why the exporters do not feel the cost of local vegetable production is low enough to be competitive in the global market. Similarly, the ability to increase the prices of local traders to make good profits when production is less.

So, whatever the cost of product and level of production of vegetables, local traders consider it as no barrier for their business operations. Traders at Narsingdi and Gazipur informed us that they can procure any quantity of products at a high price if there is a shortage of vegetable production and therefore do not consider level as a barrier to get enough supply for their trade. The exporters cannot bear the extra price of low-level production and considering the level of production is not large enough to meet the demand of the international market. The profitability of the supply chain is not a concern for local traders and exporters.

\section{Vegetable Grower Always Loser:}

According to the present system, exporters used to get supplies of vegetables from Vegetable storekeepers and Merchant. They only receive good quality products; Hence, the post-harvest loss and shrinkage do not affect the exporters. This is the concern of the local traders because they carry economic losses associated with it. Climaterelated to fluctuating supply of vegetables affect the local traders by reducing the supply of vegetables. Exporters do not bear the burden to procure the produces from the growers, hence they are less sensitive to climate-related fluctuations. Large numbers of vegetable traders used to operate at any business cluster.

There are 50 Vegetable storekeepers at a single market in Nimshar Bazar. The existence of many traders creates price competition and often raises procurement costs. The vegetable is a perishable product and demands specialized storage and transportation facilities for effective management of the supply chain. Unfortunately, the appropriate storage facilities are not available in the country, according to the requirements of the vegetable traders. Consequently, it is difficult for the traders to maintain procured produce fresh and to avoid perishables. Hence, the lack of storage facilities is a serious bottleneck for the vegetable supply chain of Bangladesh. In the absence of suitable temperature-controlled storage facilities, the traders often use life-threatening chemicals to preserve the products for a long time.

\section{Established Suitable Cold Storage Facility:}

This study suggested establishing cold chains for the food supply chain in the country. Others suffer more than the local traders for the ineffective transport system. Local traders can make up losses from delays and failures of the transportation system by raising prices, but exporters cannot do it. Many exporters have shown dissatisfaction with delays in transport because of traffic congestions and the unavailability of adequate air freight opportunities. An ineffective transportation system can raise the operating costs of the export business. It also reduces the quality of export goods." Exporters used to get market information through Bangladeshi diaspora abroad and business houses owned by migrants of this country are the importer of local vegetables. "So, they do not need information from other sources for success in their export business. Local traders used to supply vegetables to fixed market locations and do not change their distribution plan. Hence, I do not need up-to-date market information. Food safety, hygiene, and environmental elements are the main concern of the local vegetable supply chain to meet the requirements of the international market.

\section{Needed to be Practice Hazard Analysis Critical Control Point (HACCAP):}

According to the Food \& Drug Administration (FDA) concept, HACCAP is a management system that addresses food safety by analyzing and regulating biological, chemical, and physical hazards from basic processing, procurement, and handling to the production, distribution, and consumption of the finished product." (FDA, 2018).

The understanding and practice of the HACCAP procedure for the food production and distribution system of a rustic may improve the acceptability of food items of that country within the global market. Local vegetable traders haven't any idea about the appliance of HACCAP for his or her operations. it's reduced the acceptance of 
vegetable exporters in many countries. Bangladeshi did not continue potato exports to Russia due to the importing country had imposed restrictions on the bottom, the assembly and provide a system of this country, and safety standards. consistent with the Sanitary and Phytosanitary (SPS) agreement, all countries have the right to require Sanitary and Pities for the cover of humans, animals, and plants. Countries have standard measures to make sure that food is safe for consumers and to stop the spread of pests or diseases among the population, animals, and plants.

All governments accept the very fact that some trade restrictions could also be necessary to make sure food safety and animals and health protection. Hence, the failure of the local vegetable supply chain to follow the HAP procedure and to deal with pollution prevention may restrict the access of fresh vegetable produces within the global market. the worldwide vegetable market also requires the standardization and grading of products because it ensures uniform definitions for determining levels of quality and works as a standard language for global trading. this is often also an acute weakness of the local vegetable supply chain.

\section{CHAPTER VI: RECOMMENDATION AND SUGGESTION}

Provide Training for Upgrading production and packaging system Capturing foreign Market:

There are about 157 types of vegetables from Bangladesh. There are a huge demand and potential market in different countries in the world. Almost all types of vegetables are produced in Bangladesh due to geographical reasons. Our products are in great demand in Europe. But we are not able to capture the European market due to the production and packaging system while maintaining the quality of the products. In that case, farmers are not getting their fair; prices the product is being wasted during peak season. On the other hand, as the country is losing its revenue, it is not able to play a proper role in the GDP, in this sector. Appropriate steps of the government \& the good wishes of the people involved in the sector of a Good International vegetable market of immense potential can be formed.

Here are some suggestions for the light of the issues that have been observed from this study in Field level Data Collection and Observation with Different Case study Analysis and Focus Discussion.

$>$ Needed to arrange training from farmers to export to maintain the quality of the product. At the farmer's level trained to take proper care of each vegetable to maintain the proper quality of the production of national products and arrange for appropriate monitoring.

$>$ Sorting products by grading in the case of packaging before marketing the product. In the case of product packaging, I arrange the package in the approved packaging of the buyer.

$>$ Arranged the storage for the proper storage of products. To arrange proper training for the people engaged in the work of packaging.

$>$ Arranging training for those who will monitor each subject.

$>$ The task of the government will be to form a committee consisting of the Export Promotion Bureau, Civil Aviation, and Bangladesh Agricultural Extension. The task of the committee will be to train and monitor the recruitment of appropriate observers.

$>$ The job of the seller will be to videotape everything from vegetable production to produce packaging and send it to the buyer. In the case of product packaging, where the product has been produced, what type of product has been produced by the farmer, complete specifications of the buyers are going to be written on the packaging.

$>$ Civil Aviation jobs will be arranged for sellers to book online or through the app in advance.

$>$ Vegetable perishable products are the first to be screened on a priority basis. In that case, arrange for more Exclusive Detection System (EDS) machines to be installed as required.

$>$ Appropriate steps should be taken to ensure that the garments, vegetables, and fish products are made in the Cargo Village area in separate machines.

$>$ Establishment of the storehouse at an appropriate temperature so that the quoted product can be kept at a certain temperature and then transported.

The government may take the following steps to encourage vegetable production and export. In the case of vegetable exports, transportation costs have been down to less than one dollar per kg by air. About $25 \%$ of the total cargo space can be utilized for exporting vegetables on a priority basis. 
Figure 8: Proposed Vegetable Supply Chain for International market linkages

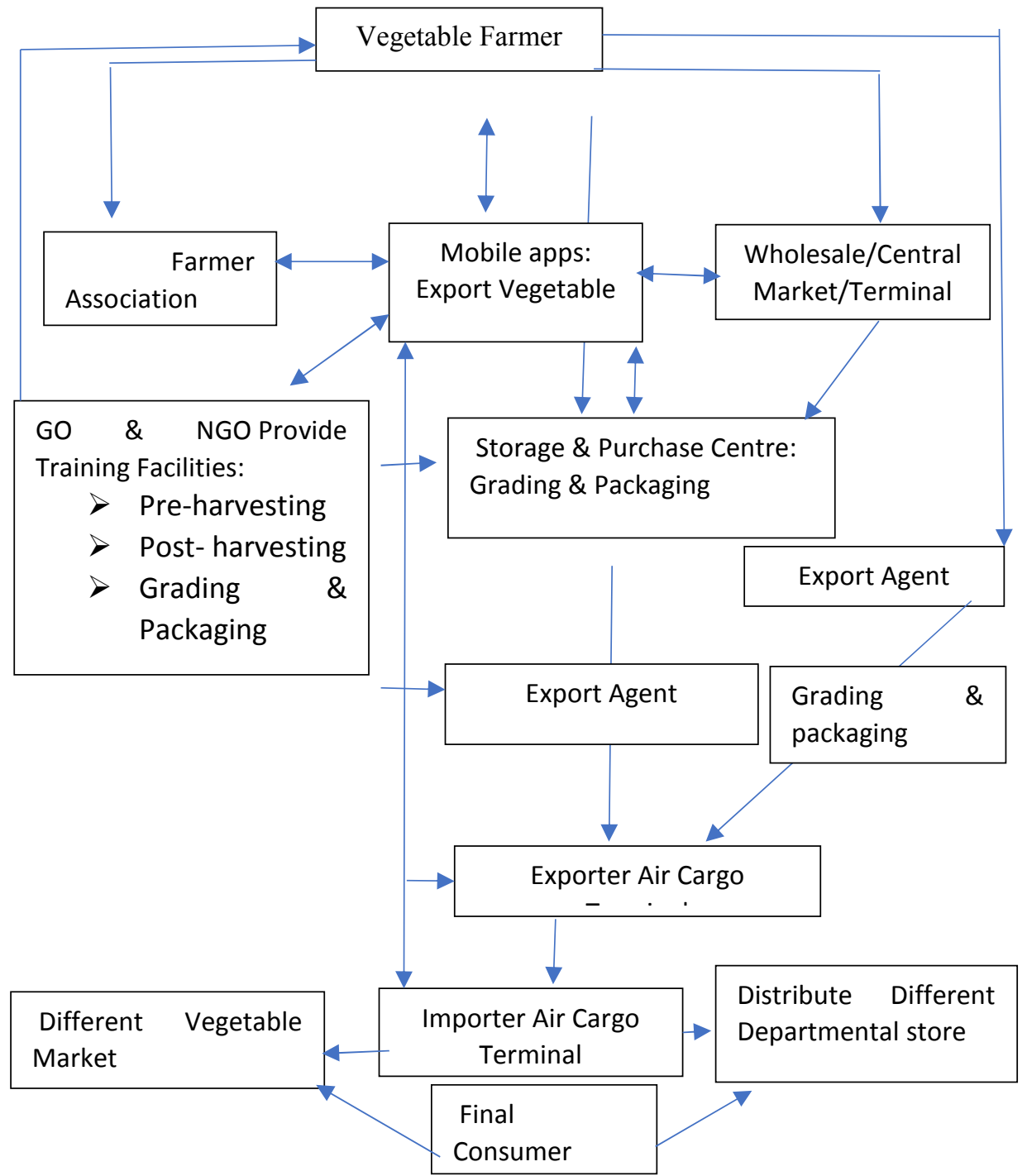

Suggestion for New entrepreneur who builds her carrier in export \& Import:

\section{Needed Professional Guideline Training for Fresher:}

Previous research by many researchers has come up with various suggestions on vegetable exports from Bangladesh. At present, the number of educated unemployed is higher in Bangladesh. Previous researchers thought so. When I was rushing to different places to collect information, I saw that educated unemployed have a chance to become entrepreneurs who can play a significant role in earning foreign exchange by exporting vegetables abroad. So, I create new content that outlines the steps you need to take to become an entrepreneur. Needed Proper and effective Training for freshers. The training will be imparted by experienced persons involved in vegetable marketing and training institutes. Especially stakeholders. And provide appropriate guidelines for marketing-related academics. It is one of the various development projects undertaken by the Government of Bangladesh. After the training, the trainees have to arrange loans and create a conducive working environment by following the appropriate guidelines. The trainees under the project will be monitored for three years to ensure that the loan is properly reflected and implemented.

Who will be Targeted Trainee:

Thirty Million educated unemployed are coming out of Bangladesh every year. But only Five Thousand people are getting first-class jobs. If this educated population can be attracted to become entrepreneurs. Then this manpower will become a human resource without being a burden for the country. The study seeks to include the steps that need to be taken in the process of talking to various stakeholders involved in vegetable exports. And in light of this, a training program can be arranged Which can be managed through 
Bangladesh Rural Development Academy (BARD). There has a complete residential training system. Who gives the certificate of import registration (IRC) \& certificate of export registration (ERC):

ERC and IRC certificates are provided by the Office of the Chief Controller of Imports \& Exports. Anyone with an Import Registration Certificate (IRC) and anyone with an Export Registration Certificate (ERC) can import and export any permissible item without restrictions on value and quantity.

The process of obtaining an IRC/ERC in Bangladesh- Necessary Documents- Step by Step:

Document 1- Attested photocopy of valid Trade License

Document 2- E-Tin Certificate

Document 3- Attested photocopy of membership certificate from local Chamber of Commerce and Industry or relevant Trade Association

Document 4- Treasury Chalan initial copy

If a partnership business: Partnership Deed (certified attested copy):

http://app.roc.gov.bd:7781/

If a limited company: (certified attested copies)

The step-by-step process of obtaining the Import Registration Certificate (IRC) or Export Registration Certificate (ERC):

Step 1: Collect IRC form from the office of Controller Import and Export.

Step 2: you must then deposit the scheduled fees at Bangladesh Bank or designated branches of Sonali Bank under the top number: 1-1731-0001-1801

The importers are classified into 6 (six) categories supported by their value ceiling of overall annual import. The initial category wise registration fees and annual renewal fees are as under:

\begin{tabular}{|l|l|l|l|}
\hline \multicolumn{1}{|c|}{ Category } & \multicolumn{1}{|c|}{$\begin{array}{c}\text { Value Ceiling of annual } \\
\text { import }\end{array}$} & \multicolumn{1}{c|}{$\begin{array}{c}\text { Initial } \\
\text { Registration fees }\end{array}$} & \multicolumn{1}{c|}{$\begin{array}{c}\text { Annual } \\
\text { renewal fees }\end{array}$} \\
\hline First & Tk. $5,00,000$ & Tk. 5,000 & Tk. 3,000 \\
\hline Second & Tk. $25,00,000$ & Tk. 10,000 & Tk. 6,000 \\
\hline Third & Tk. $50,00,000$ & Tk. 18,000 & Tk. 10,000 \\
\hline Fourth & Tk. $1,00,00,000$ & Tk. 30,000 & Tk. 15,000 \\
\hline Fifth & Tk. $5,00,00,000$ & Tk. 45,000 & Tk. 22,000 \\
\hline Sixth & Above Tk. $5,00,00,000$ & Tk. 60,000 & Tk. 30,000 \\
\hline
\end{tabular}

Exporters shall pay registration and renewal fees at the following rates:

\begin{tabular}{|l|l|l|}
\hline \multicolumn{2}{|c|}{ Initial registration fees } & Renewal fees \\
\hline Exporter & Tk. 7,000.00 & Tk. 5,000.00 \\
\hline Indentor & TK. 40,000.00 & Tk. 20,000.00 \\
\hline
\end{tabular}

Website: http://www.ccie.gov.bd/

Step 3: Submission of application form with recovery supporting documents

Time Required IRC/ERC Certificate:

Upon submission of the above documents, IRC/ERC is released manually by the Bangladesh Imports \& Exports Office within three hours, on the same day.

You can get an Import Registration Certificate (IRC) or Export Registration Certificate if you submitted a document from the Home throe Online application within a few minutes (ERC)https://olm.ccie.gov.bd/register

\section{Process of required documents:}

Document 1- Attested photocopy of valid Trade License

Who Provide Trade License in Bangladesh: In Big and little cities-City Corporation. In Village- Union Parishad. Your Business Location should be a commercial area. at the present, e-trade license certificates are easily available reception by accessing specific websites under the Ministry of government. it's given below.

http://www.etradelicense.gov.bd/URegistrationEng

Documents required for Trade License:

1. National identity card (NID), if one or another member Their NID; 
2. House owner Contact paper is written with it establish in Commercial space;

3. 4 copy Picture, if the one or another member Their Picture;

4. Tax identification number.

Document 2- Tax number (TIN) Certificate

The e-TIN certificate is easily available on the website of the National Board of Revenue of the government of Bangladesh. you will get this certificate from home. National card upload isn't required to get the e-TIN certificate online. Only by adding the amount of the national card number within the registration process the information containing the address mentioned within the card be added through the integration. The e-TIN Certificate Registration link is given as mentioned below.

https://olm.ccie.gov.bd/register

\section{Process of required documents:}

\section{Document 1- Attested photocopy of valid Trade License}

Who Provide Trade License in Bangladesh: In Big and small cities-City Corporation. In Village- Union Parishad. Your Business Location should be a commercial area. At present, e-trade license certificates are easily available at home by accessing specific websites under the Ministry of Local Government. It is given below.

http://www.etradelicense.gov.bd/URegistrationEng

\section{Documents required for Trade License:}

1. National Identity Card (NID), if one or another member Their NID;

2. House owner Contact paper is written with it establish in Commercial space;

3. 4 copy Picture, if the one or another member Their Picture;

4. Tax Identification Number.

\section{Document 2- Tax Identification Number (TIN) Certificate}

The e-TIN certificate is easily available on the website of the National Board of Revenue of the Government of Bangladesh. You will get this certificate from home. National identity card upload is not required to generate the e-TIN certificate online. Only by adding the number of the national identity card number in the registration process the information containing the address mentioned in the identity card be added through the integration. The e-TIN Certificate Registration link is given as mentioned below.

https://secure.incometax.gov.bd/TINHome

Document 3- Certified photocopy of a certificate of membership issued by the local Chamber of Commerce and Industry or the trade association concerned:

Who Provide Membership Certificate from recognized Chamber/Trade Association License in Bangladesh:

If your business in Dhaka, then you've got to require membership from the Dhaka Chamber of Commerce and Industry. If you in Chittagong, you've got to require membership from the Chittagong Chamber of Commerce and Industry. You need a membership certificate from the District Chamber of Commerce and Industry if you are in the district or town. Apart from you, a recognized Trade Association will also receive a membership certificate.

Documents required:

1) Copy of Trade license;

2) Copy of e-TIN Certificate (Original to be produced for Authentication);

3) Copy of Bank Certificate;

4) Copy of Partnership Deed of Registration Certificate and Photocopy of National ID \& individual e-TIN (applicable for partnership organization);

5) Copy of Memorandum \& Articles of Association (applicable for limited Company);

6) Photocopy of National ID \& individual e-TIN of all Directors (applicable for limited Company);

7) Copy of Certificate of Incorporation (applicable for limited Company);

8) Recently taken Passport size photograph (1 copy);

9) Copy of Visiting/Business Card of the Proprietor;

10) Copy of National Identity Card;

11) Suppose If you would like a Membership certificate from DCCI to A pay order of tk.29,350/- in favor of "Dhaka Chamber of Commerce \& Industry (DCCI)"

12) Others: VAT, IRC, ERC, venture Agreement, Copy of Passport for foreign nationals, copy of Board of Investment (BoI) permission paper, copy of labor permit.

N.B: The photocopy of all documents must be signed by the applicants with the seal of the concerned 
organization and an original copy of all documents must be shown. Any alternation of Application or overwriting or using of fluid won't be granted. (iii) Tax Identification Number;

\section{How can we get a partnership or Limited business certified attested copy? Name Registration:}

Before starting a company, a new entrepreneur must register with the Office of the Registrar of Joint Stock Companies and Companies, the online website of the Government of the People's Republic of Bangladesh, whether it is a private corporation, a partnership enterprise, a limited business or a foreign partnership enterprise. The clearance of a company name is taken because this name is already registered in the database of a company. If it is registered, then the company cannot be opened under this name because if the previous company files a case, it will have to suffer a lot of embarrassment. In the case of an application, a user ID password must be created first. The system will then automatically provide an activation code which can be found in the e-mail mentioned in the registration process. The point to be mentioned while registering the name is that the name of any government organization or corporation, the name of any famous person, the name of any well-known company mentioned above cannot be used. Whether the name you specify is already registered. You can check it directly from the system. Create a user ID and then complete the online application with company name input. In that case, you can pay the Mention fee through the three banks (Eastern Bank ltd, One Bank Ltd, \& BRAC BANK) on the website. In the case of a Private Company, Public Company, a trade organization, or Partnership companies name registration fee of BDT. 230TK. After paying the fee you will see the Company name on the RJSC(Register of Joint Stock Company) website. For online Name, Registration Visit this link.

http://app.roc.gov.bd:7781/

\section{Company Registration:}

Then you needed to pay Company Registration Fee using RJSC Calculator the calculator link is given below. If you would like to register a partnership firm, you would like to pay Total BDT. 1400. As per 1. Registration fee BDT $1,000.00$ \& 2. Registration filing fee BDT 400.00 .

If you would like to register a private Company, where Authorized Capital BDT. 20,00,000 (Twenty lac taka) you would like to pay Total BDT. 7070. As per

1. Registration fee BDT 500.00

2. Registration filing fee BDT $1,200.00$

3. Stamp of Memorandum of Association and Articles of Association Fee BDT 4150.00

4. Certified Copy MOA (Memorandum of Association) + Form XII + Digital Certificate: 1220 .

Registration Fees are going to be changed based on Authorized Capital Changes.

http://123.49.32.37:7781/psp/fee calculator

It is Noteworthy that Special Notice for Name Clearance is "This is to tell that just in case of registration of Banks, School, College, University, Hospital, television channel, News Portal, Insurance Companies and Financial Institutions, all the entrepreneurs are requested to require approval from the competent authority before applying for name clearance from the Office of Registrar Joint Stock Companies and Firms (RJSC). In default, online application for the name clearance is going to be rejected automatically."

\section{References}

Agudo, A. (2005). Measuring intake of fruit and vegetables. Geneva: World Health Organization (WHO), 1-40. Retrieved December 22, 2020, from https://apps.who.int/iris/handle/10665/43144

Alam Md Jhanagir. (2010). Export Marketing of Vegetable In Bangladesh. Cumilla: Bangladesh Academy for Rural Development. $\quad$ Retrieved $01 \quad 09, \quad 2021, \quad$ from http://library.bard.gov.bd/index.php?p=show_detail\&id=28636\&keywords=Export++Marketing ++ of ++ Veg etables++in++Bangladesh

Asian Productivity Organization, 2. (2007). Marketing System for Agricultural Products. APO, 1-20. Retrieved December 10, 2020, from https://www.apo-tokyo.org/

BBS, B. B. (2017). Yearbook of Agricultural Statistics-2017. Statistics and Informatics Division (SID), Ministry of Planning, Government of the People's Republic of Bangladesh. Retrieved 01 01, 2021, from http://www.bbs.gov.bd/site/search?key=Yearbook+of+Agricultural+Statistics-2017

Faraja Mlelwa, 2. (2013). VEGETABLE PRODUCTION AND HOUSEHOLD POVERTY REDUCTION IN LUDEWA DISTRICT. Dar Es Salaam: Mzumbe University. Retrieved from http://scholar.mzumbe.ac.tz/handle/11192/801

Fazlur, 2. (2008). Agricultural Marketing System in Bangladesh. Dhaka.: Ministry of Food. Dhaka.

FDA. (2018, 01 29). Hazard Analysis Critical Control Point (HACCP). FDA. Retrieved 12 28, 2020, from https://www.fda.gov/food/guidance-regulation-food-and-dietary-supplements/hazard-analysis-critical- 
control-point-haccp

Hossain, M. A., \& Hossain, M. N. (2013, August ). Some Observations over Supply Chain:With Reference to Vegetables Market of Bangladesh. Journal of Business Studies, , Vol. XXXIV, No. 2, 1-16. Retrieved December 22 , 2020 ,

from https://www.researchgate.net/publication/331523199_Some_Observations_over_Supply_Chain_With_Refe rence to_Vegetables_Market_of_Bangladesh

Levitt, T. (. (2016, August 05). Brexit could mean UK gets more fruit and vegetables from Africa. Guardian sustainable business. Retrieved December 19, 2020, from https://www.theguardian.com/sustainablebusiness/2016/aug/05/brexit-uk-fruit-vegetables-africa-kenya

Malakar, 2. (2006). Agricultural Marketing Systems in Bangladesh. Dhaka.: USAID/BRAC, Dhaka.

Tasnoova, S., \& Izumi Iwamto, 2. (2006). Kataribhog Rice Marketing System in Dinajpur District, Bangladesh. Mem.Fac.Agr.kagoshima univ.41, Volume 41, 19-50. Retrieved Novenber 25, 2020, from https://www.researchgate.net/publication/38409835 Kataribhog Rice Marketing System in Dinajpur Di strict_Bangladesh

Weinberger, K., \& Lumpkin, T. A. (2007). Diversification into Horticulture and Poverty Reduction: A Research Agenda. World Development. Retrieved December 18, 2020, from https://www.sciencedirect.com/science/article/abs/pii/S0305750X07000769\#!

Wisner, J. D., Tan, K.-C., \& Leong, G. K. (2012). Principles of Supply Chain Management: A Balance Approach, 3rd Edition. (3rd ed.). Cengage Learning India Private Limited. Retrieved December 10, 2020, from http://citeseerx.ist.psu.edu/viewdoc/download?doi=10.1.1.469.2022\&rep=rep1\&type=pdf 